Preliminary communication - Prethodno priopćenje

UDK: 637.112 .2

\title{
Trace elements content in cheese, cream and butter
}

\author{
doi: $10.15567 /$ mljekarstvo.2014.0302 \\ Nina Bilandžić*, Marija Sedak, Maja Đokić, Đurđica Božić, Božica \\ Solomun Kolanović, Ivana Varenina \\ Laboratory for Residue Control, Department for Veterinary Public Health, \\ Croatian Veterinary Institute, 10000 Zagreb, Croatia
}

Received - Prispjelo: 24.01.2014. Accepted - Prihvaćeno: 15.07.2014.

\begin{abstract}
Trace elements were determined in five types of cheese, cream and butter using inductively coupled plasma-optical emission spectrometry. In cheese samples trace elements were measured as follows (mg/kg): Al 0.01-3.93, Co<0.005, Cr 0.005-1.66, Li 0.008-0.056, Mn 0.068-5.37, Mo 0.003-0.225, Ni 0.01-0.163 and Sr 0.085-3.49. There were significant differences considering the concentrations of $\mathrm{Mn}, \mathrm{Cr}$ and $\mathrm{Al}(\mathrm{p}<0.01$, all) among the analysed dairy products. There were no significant differences in $\mathrm{Sr}, \mathrm{Mo}, \mathrm{Ni}$ and Li levels among products. The highest levels were found in following products $(\mathrm{mg} / \mathrm{kg}$ ): $4.23 \mathrm{Mn}$ in semi-hard fat cheese, $2.43 \mathrm{Sr}$ in cream cheese, $0.18 \mathrm{Mo}$ in cream, $0.14 \mathrm{Ni}$ and $0.028 \mathrm{Li}$ in melted cheese, $1.13 \mathrm{Cr}$ and 3.87 $\mathrm{Al}$ in butter. The trace element concentrations measured in cheeses and butter varied compared to the literature data. Concentrations of $\mathrm{Al}, \mathrm{Cr}, \mathrm{Mn}$ and $\mathrm{Mo}$ found in cheeses and $\mathrm{Mn}$ and $\mathrm{Ni}$ in butter were in line with contents reported in other countries. These results may demonstrate differences in production processes between countries. The estimated daily intakes (EDIs) calculated for $\mathrm{Cr}, \mathrm{Mn}, \mathrm{Mo}$ and $\mathrm{Ni}$ in cheeses showed a low contribution (0.59-3.38 \%) to the reference values for the permitted daily exposure (PDE) for these elements. However, the high contribution of Al concentrations (56 and $124 \%$ ) to PTWI (provisional maximum tolerable daily intake) calculated in fresh and melted cheese may pose a health risk to consumers.
\end{abstract}

Key words: cheese, dairy products, trace elements, $\mathrm{Al}, \mathrm{Co}, \mathrm{Cr}, \mathrm{Li}, \mathrm{Mn}, \mathrm{Mo}, \mathrm{Ni}, \mathrm{Sr}$, ICP-OES

\section{Introduction}

Trace elements such as lithium (Li), chromium $(\mathrm{Cr})$, manganese $(\mathrm{Mn})$, cobalt $(\mathrm{Co})$, nickel $(\mathrm{Ni})$, and molybdenum (Mo) are essential micronutrients that need to be consumed in adequate amounts for proper physiological functioning (Institute of Medicine, 2005). Optimal intakes of essential mineral elements are required to maintain peak health. Mineral deficiencies in humans are widespread throughout the world and may play a negative role on a number of physiological processes, especially in child development, pregnancy and elderly health (Grantham-McGregor and Ani, 2001). All trace elements, including essential elements, may be toxic when taken in excessive amounts, or may lead to deficiencies when taken in insufficient amounts. The presence of trace elements such as aluminium (Al) in food may come from environmental sources, such as the earth's crust and water, or due to food processing and packaging (Arnich et al., 2012).

Milk and dairy products belong to very important components of the human nutrition. They are rich in proteins, carbohydrates, fats, organic acids, enzymes, vitamins and contain more than 20 different minor and trace elements. Microelement content in milk and dairy products is normally very 
small. The highest levels measured were $\mathrm{Zn}, \mathrm{Cu}$, $\mathrm{Mg}$ and $\mathrm{Cr}$, which are essential elements and very important for normal metabolism, growth and development (Khan et al., 2014). However, through manufacturing and packaging processes, their contents may be significantly increased. Elements such as $\mathrm{Cr}$, Ni and Co may accumulate in milk and dairy products due to contamination of the environment and thus feed for ruminants (Schuhmacher et al., 1991). Elevated concentrations may cause serious health problems. The extent of toxicity is related to factors such as the route of exposure, level of intake, solubility, metal oxidation state, retention percentage, duration of exposure, age, sex, frequency of intake, absorption rate and efficiency of excretion mechanisms (Khan et al., 2014).

Several Croatian dairies produce traditional and innovative products that are popular as part of the daily consumer diet. Homemade cottage cheese is the most widespread product of traditional Croatian cheese-making practice (Kirin, 2009). To the extent of our knowledge, data on minerals and trace elements in dairy food from Croatia are limited. In recent years, studies related to trace element contents in cheese have been reported in several countries such as Brazil (Nardi et al., 2009), France (Arnich et al., 2012; Millour et al., 2012; Noël et al., 2012), Spain (González-Weller et al., 2013) and Turkey (Mendil, 2006; Merdivan et al., 2004).

The aim of this study was to determine microelement concentrations of $\mathrm{Al}, \mathrm{Co}, \mathrm{Cr}, \mathrm{Li}, \mathrm{Mn}, \mathrm{Mo}, \mathrm{Ni}$ and $\mathrm{Sr}$ in five types of cheese, butter and cream produced in Croatia and to compare these levels with those reported for other dairy products worldwide.

\section{Materials and methods}

\section{Sample collection}

In total, 17 dairy products were collected from marketplaces in Croatia: 5 types of cheeses ( 3 fresh, 2 melted, 3 cream, 3 fat soft, 3 semi-hard fat), 2 samples of cream and 2 samples of butter produced by dairy factories in Croatia. After collection, samples were placed into clean polyethylene bags, labelled and stored at $-18^{\circ} \mathrm{C}$ until analysis.

\section{Reagents}

Analytical reagent grade $\mathrm{HNO}_{3}(65 \%, \mathrm{v} / \mathrm{v})$ and $\mathrm{H}_{2} \mathrm{O}_{2}(30 \%$, v/v) were purchased from Kemika (Zagreb, Croatia). Ultra-pure water (18 MŮxcm) generated by the system NIRO VV UV UF 20 (Nirosta d.o.o. Water Technologies, Osijek, Croatia) were used for preparations of solutions.

Standard stock solutions containing $1000 \mathrm{mg} / \mathrm{L}$ of $\mathrm{Co}, \mathrm{Li}, \mathrm{Mn}, \mathrm{Mo}, \mathrm{Ni}$ and $\mathrm{Sr}$ were purchased from Inorganic Ventures (Christiansburg, VA, USA). Standard solutions containing $1000 \mathrm{mg} / \mathrm{L}$ of $\mathrm{Al}$ and Cr were supplied from Sigma-Aldrich (Buchs, Switzerland). The stock solution and working standards were diluted in $\mathrm{HNO}_{3}(0.5 \%)$.

\section{Sample preparation}

Dairy product samples ( $2 \mathrm{~g}$ ) were weighed into a PFA digestion vessel and $1 \mathrm{~mL}$ of $\mathrm{H}_{2} \mathrm{O}_{2}$ and $6 \mathrm{~mL}$ $\mathrm{HNO}_{3}$ were added. A microwave oven Multiwave 3000 (Anton Paar, Ostfildern, Germany) was used for acid digestion of samples. The digestion program consisted of step 1 at power $800 \mathrm{~W}$, ramped $15 \mathrm{~min}$, $800 \mathrm{~W}$ for $15 \mathrm{~min}$ and step II power at $0 \mathrm{~W}$ for 15 min. Digested samples were diluted with ultra-pure water to a volume of $50 \mathrm{~mL}$. Analytical batches contained a blank sample and two spiked samples.

Calculation of detection limits were performed according to three times the standard deviation of ten blanks. The limits of detection were $(\mathrm{mg} / \mathrm{kg})$ : Al 0.01, Co 0.005, Cr 0.02, Li 0.005, Mn 0.01, Mo 0.003, Ni 0.01 and Sr 0.01 .

Quality control and recovery for $\mathrm{Mn}, \mathrm{Mo}, \mathrm{Cr}$, $\mathrm{Sr}$ and Li were determined by spiking samples with known element concentrations. Good accuracy was achieved with the following recovery results (\%): $\mathrm{Al}$ 96.5, Co 95.8, Cr 96.4, Li 96.8, Mn 97.8, Mo 95.5, $\mathrm{Ni} 97.7$ and Sr 99.3.

\section{Trace element analysis}

An Optima 8000 (Perkin Elmer, Waltham, Massachusetts, USA) inductively coupled plasma optical emission spectrometer (ICP-OES) was used for element measurement. Instrumental experimental conditions are summarized in Table 1. 
Table 1. Instrumental conditions for determination of elements with inductively coupled plasma optical emission spectrometer

\begin{tabular}{lcc}
\hline Analyte & $\mathrm{Al}, \mathrm{Cr}, \mathrm{Li}, \mathrm{Mn}, \mathrm{Mo}, \mathrm{Sr}$ & $\mathrm{Co}, \mathrm{Ni}$ \\
\hline Parameter & Intensity & Intensity \\
\hline Plasma viewing mode & Axial & Axial \\
\hline Read time & $1-5 \mathrm{~s}$ & $1-5 \mathrm{~s}$ \\
\hline Measurement replicates & 3 & 3 \\
\hline RF incident power & $1300 \mathrm{~W}$ & $1400 \mathrm{~W}$ \\
\hline Plasma argon flow rate & $15 \mathrm{~L} / \mathrm{min}$ & $0.3 \mathrm{~L} / \mathrm{min}$ \\
\hline Nebulizer argon flow rate & $0.55 \mathrm{~L} / \mathrm{min}$ & $0.2 \mathrm{~L} / \mathrm{min}$ \\
\hline Auxiliary argon flow rate & $0.2 \mathrm{~L} / \mathrm{min}$ & $1.5 \mathrm{~mL} / \mathrm{min}$ \\
\hline Sample uptake rate & $1.5 \mathrm{~mL} / \mathrm{min}$ & $2.0 \mathrm{~mm}$ \\
\hline Inner diameter of the torch injector & $2.0 \mathrm{~mm}$ & Concentric glass (Meinhard) \\
\hline Nebulizer type & Concentric glass (Meinhard) & Glass cyclonic spray chamber \\
\hline Spray chamber type & Glass cyclonic spray chamber & \\
\hline
\end{tabular}

\section{Calculation of the estimated daily intake}

The estimated daily intake (EDI) was calculated by the equation (Copat et al., 2013):

EDI $(\mu \mathrm{g} /$ day $)=[($ element concentration; $\mathrm{mg} / \mathrm{kg}$ or $\mu \mathrm{g} / \mathrm{g}$ ) per (meal size or daily intake of cheese;

$$
\text { g/day)] }
$$

In the calculation, the average consumption of cheese in Croatia was set to $20 \mathrm{~g} /$ day per adult (Antonić Degač et al., 2007). The values of EDI were used to calculate contributions of each element to the reference toxicological values (PDE, permitted daily exposure; PTWI, provisional maximum tolerable daily intake).

\section{Data analysis}

Statistical analysis was conducted using Statistica 6.1 software (StatSoft ${ }^{\circledR}$ Inc., Tulsa, USA). Concentrations were expressed as mean $\pm \mathrm{SD}$. One-way ANOVA was used to test statistical differences in element levels between the analysed dairy products. Results were considered significant at $\mathrm{p} \leq 0.05$.

\section{Results and discussion}

Dietary intakes of trace elements, and therefore in various milk and dairy products, are of great concern for public health, and need to be monitored on a regular basis. The presence of trace elements might indicate qualitative parameters in the production procedures, sanitary conditions, and quality of animal feeding which can affect milk and cheese characteristics, storage or health aspects. Also, some trace elements are correlated to environmental pollution and to releases from packaging and milking equipment in the dairy production (Bakircioglu et al., 2011).

The results of the trace element content (Al, $\mathrm{Cr}, \mathrm{Li}, \mathrm{Mn}, \mathrm{Mo}, \mathrm{Ni}$ and $\mathrm{Sr}$ ) in five cheese types, butter and cream, the mean concentrations and the standard deviations (SDs) are presented in Table 2. Statistically significant differences in concentrations of $\mathrm{Mn}, \mathrm{Cr}$ and $\mathrm{Al}(\mathrm{p}<0.01$, all) were found among dairy products. There were no significant differences in $\mathrm{Sr}, \mathrm{Mo}, \mathrm{Ni}$ and Li levels among the products. The highest levels determined were in following products $(\mathrm{mg} / \mathrm{kg}): 4.23 \mathrm{Mn}$ in semi-hard fat cheese, $2.43 \mathrm{Sr}$ in cream cheese, $0.18 \mathrm{Mo}$ in cream, $0.14 \mathrm{Ni}$ and $0.028 \mathrm{Li}$ in melted cheese, 1.13 $\mathrm{Cr}$ and 3.87 $\mathrm{Al}$ in butter.

Cobalt is an essential trace element as a constituent of vitamin $B_{12}$ and some metalloproteins, though its toxicity in many biological systems depends on its concentration range (Antoine et al., 2012). Dietary deficiencies may lead to pernicious anaemia which 
can be fatal (McDowell, 1992). In the present study, Co levels in dairy products were measured below $0.005 \mathrm{mg} / \mathrm{kg}$. However, the Co contents reported in cheese samples from Turkey were in the range 0.009-1.54 mg/ $\mathrm{kg}$ (Merdivan et al., 2004; Bakircioglu et al., 2011).

As an essential element, $\mathrm{Ni}$ has several possible roles in the maintenance and production of cells, and as an activator of certain enzyme systems (Bakircioglu et al., 2011). However, at higher levels, the most common adverse health effect in humans is an allergic reaction. Nickel contamination in food may be due to environmental contamination or from production or storage processes of food such as drying, cooking and packaging (Bakircioglu et al., 2011). In the present study, variations in Ni content between cheese types were measured (0.041-0.14 mg/kg). The highest Ni content was determined in melted $(0.12 \mathrm{mg} / \mathrm{kg})$ and fat soft cheese $(0.14 \mathrm{mg} / \mathrm{kg})$. Measured concentrations were $1.5-8$ times lower than those reported in Turkey and France (Mendil, 2006; Arnich et al., 2012). Very high levels of Ni of 1.14 $\mathrm{mg} / \mathrm{kg}$ were measured in white cheese from Turkey (Merdivan et al., 2004). Concentrations found in butter in this study were similar to levels determined in Brazil by Nardi et al. (2009).

Chromium $(\mathrm{Cr})$ is widely found in the environment. However, the main source of the environmental contamination by $\mathrm{Cr}$ is its release from stainless steel containers (Bakircioglu et al., 2011). Regarding concentrations of $\mathrm{Cr}$ in foods of animal origin, the highest levels are found in oysters and liver, while low contents are reported for meat (Linder, 1988; Aranda and Llopis, 1993). Chromium is an essential element in carbohydrate metabolism as a component of the glucose tolerance factor, and is involved in cardiovascular risk and metabolic syndrome (Hummel et al., 2007). In this study, $\mathrm{Cr}$ in cheeses was found in the mean range of $0.11-0.83 \mathrm{mg} / \mathrm{kg}$ and the highest content of 1.13 $\mathrm{mg} / \mathrm{kg}$ was measured in butter samples.

Chromium concentrations measured in cheese samples were similar, though butter samples contained approximately 2-11 times higher concentrations than those reported in Brazil and France (Nardi et al., 2009; Noël et al., 2012). In contrast to that, lower $\mathrm{Cr}$ contents were found in two types of Spanish cheese (González-Weller et al., 2013).

Although it is considered an essential element, chronic exposure to lithium (Li) is often associated with toxic effects. Adverse metabolic effects of Li were described for various internal organs and are related to the cardiovascular system, central and peripheral nervous systems, kidneys, gastrointestinal tract and skin, and can also cause changes in

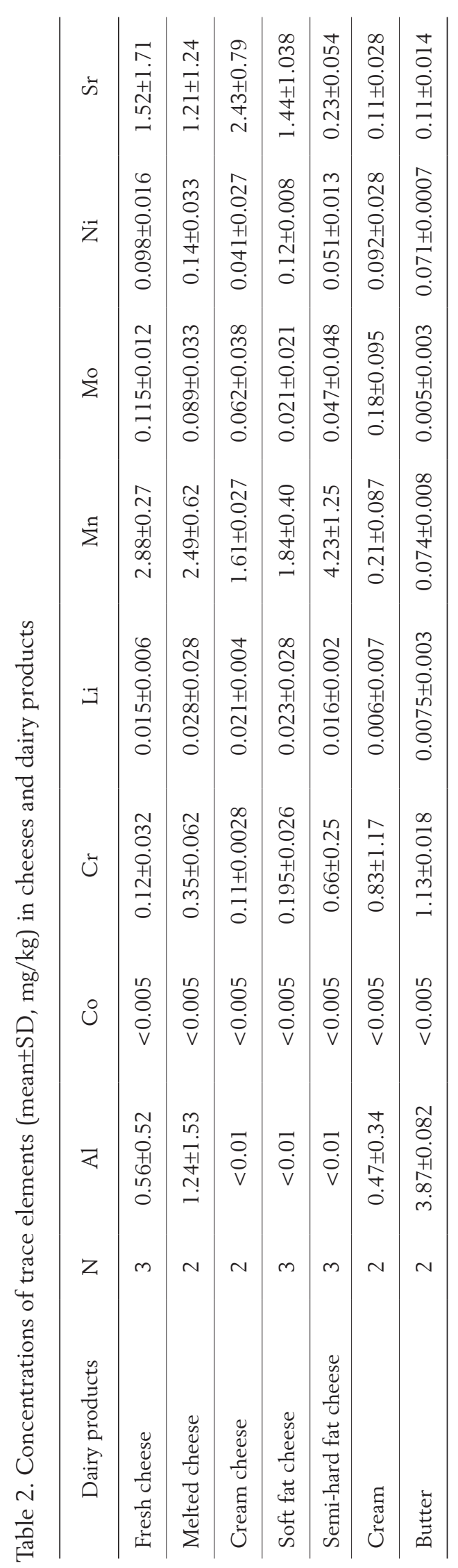


Table 3. Trace elements concentrations $(\mathrm{mg} / \mathrm{kg})$ in dairy samples from other countries

\begin{tabular}{|c|c|c|c|c|c|c|c|c|c|c|}
\hline Country & $\begin{array}{l}\text { Cheese } \\
\text { type }\end{array}$ & $\mathrm{Al}$ & Co & $\mathrm{Cr}$ & $\mathrm{Li}$ & $\mathrm{Mn}$ & Mo & $\mathrm{Ni}$ & $\mathrm{Sr}$ & Reference \\
\hline \multirow{2}{*}{ Spain } & $\begin{array}{l}\text { Fresh } \\
\text { cheese }\end{array}$ & & & 0.010 & 4.022 & & & & 3.031 & \multirow{2}{*}{$\begin{array}{c}\text { González- } \\
\text { Weller et } \\
\text { al., } 2013\end{array}$} \\
\hline & $\begin{array}{c}\text { Hard } \\
\text { cheese }\end{array}$ & & & 0.015 & 1.535 & & & & 11.99 & \\
\hline \multirow{3}{*}{ France } & \multirow{3}{*}{ Cheese } & 0.63 & & & & & & & 0.004 & $\begin{array}{c}\text { Millour et } \\
\text { al., } 2012\end{array}$ \\
\hline & & & 0.0153 & & & & & 0.202 & & $\begin{array}{c}\text { Arnich et } \\
\text { al., } 2012\end{array}$ \\
\hline & & & & 0.173 & 1.89 & 0.184 & 0.076 & & & $\begin{array}{c}\text { Noël et al., } \\
2012\end{array}$ \\
\hline \multirow{3}{*}{ France } & \multirow{3}{*}{ Butter } & 2.10 & & & & & & & 0.238 & $\begin{array}{c}\text { Millour et } \\
\text { al., } 2012\end{array}$ \\
\hline & & & 0.046 & & & & & 0.046 & & $\begin{array}{c}\text { Arnich et } \\
\text { al., } 2012\end{array}$ \\
\hline & & & & 0.636 & & 0.038 & 0.440 & & & $\begin{array}{c}\text { Noël et al., } \\
2012 \\
\end{array}$ \\
\hline Brazil & Cheese & 0.09 & & 0.14 & & 0.25 & 0.075 & 0.043 & 1.2 & $\begin{array}{l}\text { Nardi et } \\
\text { al., } 2009\end{array}$ \\
\hline Brazil & Butter & 0.09 & 0.0019 & 0.10 & & 0.09 & 0.042 & 0.034 & 0.068 & $\begin{array}{l}\text { Nardi et } \\
\text { al., } 2009\end{array}$ \\
\hline \multirow{2}{*}{ Turkey } & $\begin{array}{l}\text { White } \\
\text { cheese }\end{array}$ & & & $0.02-0.55$ & & $0.28-1.1$ & & $0.18-.0 .34$ & & $\begin{array}{l}\text { Mendil, } \\
2006\end{array}$ \\
\hline & $\begin{array}{l}\text { White } \\
\text { cheese }\end{array}$ & 2.37 & 0.200 & 0.058 & & 0.052 & 0.34 & 1.14 & & $\begin{array}{l}\text { Merdivan } \\
\text { et al., } 2004\end{array}$ \\
\hline
\end{tabular}

calcium levels, interference with glucose metabolism, hypothyroidism, hyperparathyroidism and weight gain (Paquet et al., 2005; González-Weller et al., 2013). In this study, Li levels ranged from 0.015$0.028 \mathrm{mg} / \mathrm{kg}$ in cheeses, and were approximately 2.5-3.7 times lower in cream and butter samples than in cheeses. These values are significantly lower than levels reported from the literatures (Noël et al., 2012; González-Weller et al., 2013).

Molybdenum(Mo) is an essential trace nutrient and plays an important role in the regulation of $\mathrm{Ca}$, $\mathrm{Mg}$ and $\mathrm{Cu}$ metabolism. It is biologically active as a co-factor to several enzymes, as well as the oxidation of sulphite and the formation of uric acid (McDowell, 1992). In this study, the lowest and highest Mo concentrations were found in butter $(0.005 \mathrm{mg} /$ $\mathrm{kg})$ and fresh cheese $(0.115 \mathrm{mg} / \mathrm{kg})$. Molybdenum contents in cheese samples were within this range, though the content in butter was significantly lower than the literature data presented in Table 3.
Aluminium (Al) has no essential function in human health, and its toxic effects have been established for the central nervous, skeletal and hematopoietic systems (Krewski et al., 2007). Although different food sources contribute variable amounts of $\mathrm{Al}$ to the diet, the greatest amount of $\mathrm{Al}$ is added through the FDA-approved food additive usage of sodium aluminium phosphates as an emulsifying salt (Lopez et al., 2002; Yokel et al., 2008). This salt is permitted by the FDA up to $3 \%$ in pasteurized processed cheese. It is added during cheese processing to react with the proteins in cheese in order to create a smooth, uniform film around each fat droplet which prevents separation and the bleeding of fat from cheese. In processed cheeses, levels of 320 (Pennington and Schoen, 1995) and $470 \mathrm{mg} \mathrm{Al} /$ $\mathrm{kg}$ (Saiyed and Yokel, 2005) were reported. The highest levels of Al recently reported were in crustaceans and molluscs $(21.1 \mathrm{mg} / \mathrm{kg})$ and in chocolate $(15.6 \mathrm{mg} / \mathrm{kg})$, while in other food groups, including 
dairy products, $\mathrm{Al}$ contents were generally lower than $6 \mathrm{mg} / \mathrm{kg}$ (Arnich et al., 2012). In this study, the Al content determined in fresh and processed cheese are in agreement with reported data from France (Millour et al., 2012) but lower than those from Turkey (Merdivan et al., 2004). Alvalues measured in butter were 2-43 times higher than those reported previously (Nardi et al., 2009; Millour et al., 2012).

Manganese $(\mathrm{Mn})$ is recognised as an essential trace element for humans, and its metabolic role includes Mn-containing enzyme systems (Reykdal et al., 2011). The Mn contents in cheese samples were between 1.61-4.23 mg/kg and the lowest and highest $\mathrm{Mn}$ concentrations were found in cream cheese and semi-hard fat cheese. The estimated Mn values were in agreement with those reported earlier in cheese and butter (Mendil, 2006; Nardi et al., 2009; Noël et al., 2012).

The biological role of strontium has not been clearly established and is generally regarded as nontoxic (Bonjour et al., 2009). As an alkali metal with chemical similarity to calcium, the toxicity of Strontium $(\mathrm{Sr})$ is due to its interference in biological processes involving calcium, primarily sceletogenesis (Oste et al., 2005). In this study, Sr content ranged from $0.074-2.43 \mathrm{mg} / \mathrm{kg}$ in cheese products. The content of $\mathrm{Sr}$ in cream and butter was similar and was 2-22 times lower than in cheeses. These results were lower than those recorded for cheeses from Spain (González-Weller et al., 2013) and butter from France (Millour et al., 2012).

To evaluate the measured element levels in cheese samples from the risk assessment perspective, the estimated daily intake (EDI) was calculated and compared with reference toxicological values. For the purposes of national and international health authorities and institutes, World Health Organization (WHO) has reported some critical levels for minor and trace elements, such as the provisional maximum tolerable daily intake (PMTDI) level, the provisional tolerable weekly intake level (PTWI), the dietary reference intakes (DRI) and the total dietary intakes (TDI), an upper level (UL) and the acceptable daily intake (ADI). However, to avoid the confusion of differing values for ADI's of the same substance the permitted daily exposure (PDE) was

Table 4. Estimated daily intakes (EDIs) of elements for the two highest mean concentrations among cheeses and contribution to reference toxicological values

\begin{tabular}{|c|c|c|c|}
\hline Element/Cheese & $\mathrm{EDI}^{\mathrm{a}}(\mu \mathrm{g} /$ day $)$ & $\mathrm{PDE}^{\mathrm{b}}$ or $\mathrm{PTWI}^{\mathrm{c}}(\mu \mathrm{g} /$ day $)$ & Contribution of EDI to PDE or PTWI (\%) \\
\hline \multicolumn{4}{|c|}{$\mathrm{Al}$} \\
\hline Fresh cheese & 11.2 & \multirow{2}{*}{20} & 56 \\
\hline Melted cheese & 24.8 & & 124 \\
\hline \multicolumn{4}{|c|}{$\mathrm{Cr}$} \\
\hline Melted cheese & 7.00 & \multirow{2}{*}{250} & 2.80 \\
\hline Soft fat cheese & 3.90 & & 1.56 \\
\hline \multicolumn{4}{|c|}{$\mathrm{Mn}$} \\
\hline Semi-hard fat cheese & 84.6 & \multirow{2}{*}{2500} & 3.38 \\
\hline Fresh cheese & 57.6 & & 2.30 \\
\hline \multicolumn{4}{|c|}{ Mo } \\
\hline Fresh cheese & 2.30 & \multirow{2}{*}{300} & 0.77 \\
\hline Melted cheese & 1.78 & & 0.59 \\
\hline \multicolumn{4}{|c|}{$\mathrm{Ni}$} \\
\hline Melted cheese & 2.80 & 300 & 0.93 \\
\hline Soft fat cheese & 2.40 & & 0.80 \\
\hline
\end{tabular}

${ }^{a}$ EDI was calculated by the equation: [(element concentration; $\mathrm{mg} / \mathrm{kg}$ or $\mu \mathrm{g} / \mathrm{g}$ ) per (meal size or daily intake of food; $\mathrm{g} / \mathrm{day}$ )] (Copat et al., 2013). Meal size of cheese: $20 \mathrm{~g}$ /day per adult (Antonić Degač et al., 2007)

bPDE (permitted daily exposure)

cPTWI (provisional tolerable weekly intake level) 
defined as the pharmaceutically maximum acceptable exposure to residual metals on a chronic basis that is unlikely to produce any adverse health effects (EMEA, 2008). The PDE valued defined for $\mathrm{Cr}, \mathrm{Mn}, \mathrm{Mo}$ and Ni were: Cr $250 \mu \mathrm{g}$ /day (for a 50 $\mathrm{kg}$ individual: $0.005 \mathrm{mg} / \mathrm{kg} /$ day); $\mathrm{Mn} 2.5 \mathrm{mg} /$ day; Mo $300 \mu \mathrm{g} /$ day; Ni $300 \mu \mathrm{g} /$ day (6 $\mu \mathrm{g} \mathrm{Ni} / \mathrm{kg} /$ day in a $50 \mathrm{~kg}$ person). A Joint FAO (Food and Agriculture Organization of the UN)/WHO Expert Committee on Food Additives established a revised provisional tolerable weekly intake (PTWI) for Al in food, of $1 \mathrm{mg} / \mathrm{kg} / \mathrm{bw}$ or $20 \mu \mathrm{g} /$ day for a $50 \mathrm{~kg}$ person $(\mathrm{FAO} /$ WHO, 2006). However, WHO did not define any nutritional or toxicological references for $\mathrm{Co}, \mathrm{Li}$ and Sr (Leblanc et al., 2005).

Table 4 contains the estimated daily intakes (EDI) of Al, Cr, Mn, Mo and Ni for the two cheeses with the highest mean concentrations. EDI was not calculated for cream and butter due to the lack of the available literature data for the average consumption in Croatia. The contribution of EDI values to the reference toxicological values (PDE, permitted daily exposure; PTWI, provisional maximum tolerable daily intake) were calculated for each element. Therefore, the EDIs calculated for the highest two mean values showed a contribution to the PDE values for elements: Mo and Ni below $1 \%$; $\mathrm{Mn}$ and $\mathrm{Cr}$ between 1.5 and 3.5\%. However, EDIs values calculated for contribution of $\mathrm{Al}$ for fresh and melted cheese showed a high contribution (56 and $124 \%)$ to PTWI value.

\section{Conclusions}

Significant differences in the concentrations of trace elements $\mathrm{Mn}, \mathrm{Cr}$ and $\mathrm{Al}$ were observed between cheeses and butter. There were no significant differences in levels of $\mathrm{Sr}, \mathrm{Mo}, \mathrm{Ni}$ and $\mathrm{Li}$ among the tested products. Concentrations of $\mathrm{Al}, \mathrm{Cr}, \mathrm{Mn}$ and $\mathrm{Mo}$ found in cheeses were in line with contents reported in other countries. However, $\mathrm{Co}, \mathrm{Li}, \mathrm{Ni}$ and $\mathrm{Sr}$ were lower in comparison to the available literature data. Trace elements measured in butter showed higher $\mathrm{Al}$ and $\mathrm{Cr}$, lower $\mathrm{Co}$, Mo and $\mathrm{Sr}$, and similar Mn and Ni concentrations in comparison to previous reports. These results may demonstrate differences in production processes between countries.

Regarding the risk assessment results, it is unlikely that the intake of $\mathrm{Cr}, \mathrm{Mn}, \mathrm{Mo}$ and Ni through cheeses and dairy products would involve any risk for the average consumer. However, the high values for $\mathrm{Al}$ determined in fresh and melted cheese in comparison to the toxicity reference values may pose a health risk to consumers.

The results demonstrate the trace element distribution in the tested dairy products and may be important for the assessment of the nutritional and toxicological values for each element.

\section{Sadržaj elemenata u tragovima u siru, vrhnju i maslacu}

\section{Sažetak}

Elementi u tragovima određeni su u pet vrsta sira, vrhnju i maslacu primjenom induktivno spregnute plazme-optičke emisijske spektrometrije. U uzorcima sira određeni su elementi u tragovima u rasponu (mg/kg): Al 0,01-3,93, Co<0,005, Cr 0,005-1,66, Li 0,008-0,056, Mn 0,068-5,37, Mo $0,003-0,225$, Ni 0,01-0,163 i Sr 0,085-3,49. Utvrđene su statistički značajne razlike u koncentracijama Mn, Cr i Al ( $<<0,01$, svi) između mliječnih proizvoda. Nije bilo značajnih razlika u koncentracijama Sr, Mo, Ni i Li među proizvodima. Najviše koncentracije izmjerene su u proizvodima $(\mathrm{mg} / \mathrm{kg})$ : Mn 4,23 za polutvrdi masni sir, Sr 2,43 za krem sir, Mo 0,18 za vrhnje, Ni 0,14 i Li 0,028 za topljeni sir, Cr 1,13 i Al 3,87 za maslac. Koncentracije elementa u tragovima u sirevima i maslacu varirale su u usporedbi s podacima iz literature. Koncentracije $\mathrm{Al}, \mathrm{Cr}$, Mn i Mo u sirevima te Mn i Ni u maslacu bile su u skladu sa sadržajem utvrđenim u drugim zemljama. Ovi rezultati pokazuju razlike u proizvodnim procesima između zemalja. Dnevni unosi (eng. EDIs, estimated daily intakes) izračunati za $\mathrm{Cr}, \mathrm{Mn}, \mathrm{Mo} \mathrm{i}$ $\mathrm{Ni}$ u sirevima pokazuju mali doprinos $(0,59-3,38 \%)$ prema vrijednostima dopuštenih dnevnih izloženosti (eng. PDE, permitted daily exposure) određenih za te elemente. Međutim, visoki doprinos Al (56 i $124 \%$ ) prema PTWI vrijednosti (eng. provisional maximum tolerable daily intake) u svježem i topljenom siru može predstavljati rizik za zdravlje potrošača.

$$
\begin{aligned}
& \text { Ključne riječi: sir, mliječni proizvodi, } \\
& \text { elementi u tragovima, } \mathrm{Al}, \mathrm{Co}, \mathrm{Cr}, \mathrm{Li}, \\
& \mathrm{Mn}, \mathrm{Mo}, \mathrm{Ni}, \mathrm{Sr} \text {, ICP-OES }
\end{aligned}
$$




\section{References}

1. Antoine, J.M.R., Fung, L.A.H., Grant, C.N., Dennis, H.T., Lalor, G.C. (2012): Dietary intake of minerals and trace elements in rice on the Jamaican market. Journal of Food Composition and Analysis 26, 111-121. doi: dx.doi.org/10.1016/j.jfca.2012.01.003

2. Antonić Degač, K., Laido, Z., Kaić-Rak, A. (2007): Obilježja prehrane i uhranjenosti stanovništva Hrvatske. Hrvatski zavod za javno zdravstvo. Hrvatski časopis za javno zdravstvo 3, 9.

3. Arnich, N., Sirot, V., Rivière, G., Jean, J., Noël, L., Guérin, T., Leblanc, J.-L. (2012): Dietary exposure to trace elements and health risk assessment in the 2nd French Total Diet Study. Food and Chemical Toxicology 50, 2432-2449. doi: dx.doi.org/10.1016/j.fct.2012.04.016

4. Bakircioglu, D., Bakircioglu Kurtulus, Y., Ucar, G. (2011): Determination of some traces metal levels in cheese samples packaged in plastic and tin containers by ICP-OES after dry, wet and microwave digestion. Food and Chemical Toxicology 49, 202-207. doi: dx.doi.org/10.1016/j.fct.2010.10.017

5. Bonjour, J.-P., Gueguen, L., Palacios, C., Shearer, M.J., Weaver, C.M. (2009): Minerals and vitamins in bone health: the potential value of dietary enhancement. British Journal of Nutrition 101, 1581-1596. doi: dx.doi.org/10.1017/S0007114509311721

6. Copat, C., Arena, G., Fiore, M., Ledda, C., Fallico, R., Sciacca, S., Ferrante, M. (2007): Heavy metals concentrations in fish and shellfish from eastern Mediterranean Sea: Consumption advisories. Food and Chemical Toxicology 53, 33-37. doi: dx.doi.org/10.1016/j.fct.2012.11.038

7. EMEA (2008): Guideline on the specification limits for residues of metal catalysts. Doc. Ref. EMEA/CHMP/ SWP/4446/2000. London, UK.

8. FAO/WHO (2006): Summary and Conclusions of the 67th Meeting of the Joint FAO/WHO Expert Committee on Food Additives (JECFA), 67th Meeting in Rome, 20-29 June 2006, issued 7 July, 2006. At: (http://www. who.int/ipcs/food/jecfa/jecfa67_call\%20final.pdf/).

9. González-Weller, D., Rubio, C., Gutiérrez, A.J., González, G.L., Mesa, J.M.C., Gironés, C.R., Ojeda, A.B., Hardisson, A. (2013): Dietary intake of barium, bismuth, chromium, lithium, and strontium in a Spanish population (Canary Islands, Spain). Food and Chemical Toxicology 62, 856-868. doi: dx.doi.org/10.1016/j.fct.2013.10.026

10. Hummel, M., Standl, E., Schnell, O. (2007): Chromium in metabolic and cardiovascular disease. Hormone and Metabolic Research 39, 743-751. doi: dx.doi.org/10.1055/s-2007-985847

11. Khan, N., Jeong, I.S., Hwang, I.M., Kim, J.S., Choi, S.H., Nho, E.Y., Choi, J.Y., Park, K.S., Kim, K.S. (2014): Analysis of minor and trace elements in milk and yogurts by inductively coupled plasma-mass spectrometry (ICP-MS). Food Chemistry 147, 220-224. doi: dx.doi.org/10.1016/j.foodchem.2013.09.147
12. Leblanc, J.-L., Guérin, T., Noël, L., Calamassi-Tran,G., Volatier, J.-L., Verger, P. (2005): Dietary exposure estimates of 18 elements from the 1st French Total Diet Study. Food Additives and Contaminants 22 (7), 624-641. doi: dx.doi.org/10.1080/02652030500135367

13. McDowell, L.R. (1992): Minerals in Animal and Human Nutrition. Academic Press Inc., CA, USA.

14. Krewski, D., Yokel, R.A., Nieboer, E., Borchelt, D., Cohen, J., Harry, J., Kacew, S., Lindsay, J., Mahfouz, A.M., Rondeau, V. (2007): Human health risk assessment for aluminium, aluminium oxide, and aluminium hydroxide. Journal of Toxicology and Environmental Critical Reviews 10 (Suppl. 1), 1-269.

15. Lopez, F.E., Cabrera, C., Lorenzo, M.L., Lopez, M.C. (2002): Aluminum levels in convenience and fast foods: in vitro study of the absorbable fraction. Science of the Total Environment 300, 69-79. doi: dx.doi.org/10.1016/S0048-9697(02)00282-6

16. Millour, S., Noël, L., Chekri, R., Kadar, A., Vastel, C., Sirot, V., Leblanc, J.-L., Guérin, T. (2012): Strontium, silver, tin, iron, tellurium, gallium, barium and vanadium levels in foodstuffs from the second French Total Diet Study. Journal of Food Composition and Analysis 25, 108-129. doi: dx.doi.org/10.1016/j.jfca.2011.10.004

17. Nardi, E.P., Evangelista, F.S., Tormen, L., Saint'Pierre, T.D., Curtius, A.J., de Souza, S.S., Barbosa, F. (2009): The use of inductively coupled plasma mass spectrometry (ICP-MS) for the determination of toxic and essential elements in different types of food samples. Food Chemistry 112, 727-732. doi: dx.doi.org/10.1016/j.foodchem.2008.06.010

18. Noël, L., Chekri, R., Millour, S., Vastel, C., Kadar, A., Sirot, V., Leblanc, J.-L., Guérin, T. (2012): Li, Cr, Mn, $\mathrm{Co}, \mathrm{Ni}, \mathrm{Cu}, \mathrm{Zn}$, Se and Mo levels in Foodstuffs from the $2^{\text {nd }}$ French TDS. Food Chemistry 132, 1502-1513. doi: dx.doi.org/10.1016/j.foodchem.2011.12.009

19. Oste, L., Bervoets, A.R., Behets, G.J., Dams, G., Marijnissen, R.L., Geryl, H., Lamberts, L.V., Verberckmoes, S.C., Van Hoof, V.O., De Broe, M.E., D'Haese, P.C. (2005): Time-evolution and reversibility of strontium-induced osteomalacia in chronic renal failure rats. Kidney International 67, 920-930. doi: dx.doi.org/10.1111/j.1523-1755.2005.00156.x

20. Paquet, P., Claessens, N., Pierard-Franchimont, C., Pierard, G.E. (2005): Cutaneous adverse effects of lithium. Revue Medicale de Liege 60, 885-887.

21. Pennington, J.A.T., Schoen, S.A. (1995): Estimates of dietary exposure to aluminium. Food Additives and Contaminants 12, 119-128. doi: dx.doi.org/10.1080/02652039509374286

22. Reykdal, O., Rabieh, S., Steingrimsdottir, L., Gunnlaugsdottir, H. (2011): Minerals and trace elements in Icelandic dairy products and meat. Journal of Food Composition and Analysis 124, 980-986. doi: dx.doi.org/10.1016/j.jfca.2011.03.002 
23. Saiyed, S.M., Yokel, R.A. (2005): Aluminium content of some foods and food products in the USA, with aluminium food additives. Food Additives and Contaminants 22, 234-244. doi: dx.doi.org/10.1080/02652030500073584

24. Schuhmacher, M., Borques, A.M., Domingo, L.J., Carbella, J. (1991): Dietary intake of lead and cadmium from foods in Tarragona Province, Spain. Bulletin of Environmental Contamination and Toxicology 46 (2), 320-328. doi: dx.doi.org/10.1007/BF01691955
25. Yokel, R.A.,Hicks, C.L., Florence, R.L. (2008): Aluminum bioavailability from basic sodium aluminum phosphate, an approved food additive emulsifying agent, incorporated in cheese. Food and Chemical Toxicology 46, 2261-2266. doi: dx.doi.org/10.1016/j.fct.2008.03.004 